Longina

Strumska-Cylwik

Longina Strumska-

Cylwik, Division of General

Pedagogy, Social Science

Faculty, University of

Gdańsk, Poland;

Email: I.strumska@ug.edu.

pl;ginacylwik@gmail.com

DOI: http://dx.doi.

org/10.18820/24150479/

aa57i2.5

ISSN:0587-2405

e-ISSN: 2415-0479

Acta Academica - 2019 51(2):

93-99

(c) Creative Commons With Attribution (CC-BY)

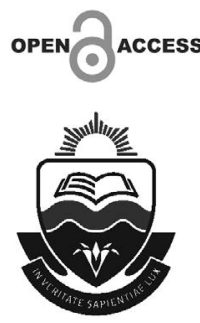

\section{The poverty of (critical) theory: a review}

Published: 9 December 2019

The subject of this review is the paper ${ }^{-1}$ by Bert Olivier ${ }^{2}$ titled "The poverty of (critical) theory", a work to which one cannot remain indifferent. It provokes one into discussion, touches one's conscience, fills one with bitter reflection on the condition of critical theory and the condition of humanity and the modern world, and at the same time it induces fear for their future fate.

This paper is extremely important, given the prospect of the dynamic civilisational changes of the modern world, and the resulting cultural, economic, political, social and ecological dilemmas (on the one hand, the extremely dynamic development of modern technologies, the market economy and global culture; and on the other hand, the economic crisis, the accompanying devastation of the ecosystem and, as a result of these crises, increasing poverty, hunger, destitution, immigration problems, etc.). They all inspire reflective people to look for solutions and specific actions, and the paper in question exhorts one to engage in such (critical) actions, instead of mere critical thinking.

The analysis/review in its context has been carried out from the perspective of the reviewer's main research interests, focused on interpersonal

1 This paper was first presented at the inaugural Symposium of the South African Society of Critical Theory in Bloemfontein, South Africa, on 17 November 2017, and was published in Acta Academica 50 (2), 2018, pp. 1-39.

2 Bert Olivier is an Extraordinary Professor of Philosophy at the University of the Free State in South Africa. 
communication and the search for educational implications and meanings. By articulating her own view of the text, the reviewer determines (in accordance with the idea of critical theory) her own position as both a teacher and a communication researcher. In this context, she is interested in the critical (though concerned) view of the author of the text.

In his article, Olivier follows many leading thinkers (such as Max Horkheimer, Theodor Adorno, Immanuel Kant, Gil Germain, Antonio Negri, Michael Hardt, and others), and in an uncompromising but consistent way reveals the "poverty of (critical) theory", which, in his opinion, is incapable of making a fundamental and radical (as well as effective) transition from theoretically verified sources of alienation and oppression to actual emancipation.

As a representative manifestation of this poverty, he recalls the triumph of neoliberalism in the world (refuting the belief that theory is equipped with emancipatory resources enabling the transformation of the world or society) and post-theory (that rejects the belief that theory has any epistemological value and effectiveness); in the latter case the author clearly distances himself from naïve post-theoretical assertions.

It is worth noting that Olivier, in his deliberations, is not afraid to use expressive (sometimes risky, provocative) comparisons that allow one to discover, or that bring to light, the spurious nature of so-called neoliberal 'freedom' (which is widely believed to be non-consensual and which excludes whole masses of people); therefore, the neoliberal world appears in his deliberations quite clearly as a totalising world. Such a picture, clearly presented by the author in an extremely suggestive and eloquent way, turns out to be a very effective way to reach our imagination and conscience. We notice this clearly in the bold comparison of the contemporary image of the world with the Orwellian vision of a totalitarian world (with the emphasis that the totalitarianism of the contemporary world is much subtler in its form).

Following the thought of Gil Germain, articulated in his latest book, Thinking about Technology. How the Technological Mind Misreads Reality 3 , Olivier expresses deep concern about the direction of contemporary society under the yoke of ubiquitous information technologies, which, in his opinion and informed

3 Gil Germain emphasises that the "technological mind" shows a tendency to interpret reality in a wrong/incorrect way (distorting the nature of reality), insofar as its relative independence from human beings is overlooked because of technological imperatives to construct a world completely of human making. At the same time, the world that people create is perceived from the perspective of a 'technological landscape', in this way covering up the fact that reality is fundamentally not of human creation. 
by several of his critical sources (particularly Bernard Stiegler), gradually take control and mastery over humanity and its social environment, at the same time gradually quashing the "core of human existence". The author observes this phenomenon with concern, noticing at the same time that in accordance with the spirit of consumer culture, information technologies force people to constantly chase after something and "strive towards some kind of fulfillment" (though, as he emphasises, this pursuit seems to be unspecified), on the assumption that consuming is capable of 'delivering' such fulfilment. However, Olivier points to the fact that Germain, referring to Plato's Phaedrus, reminds one that, in principle, conclusive fulfilment is not possible for human beings, as there is always a 'lack' of something, and always something 'more' and 'other' to strive towards. This is why, especially in a culture that promotes consumption values, it is not merely illusory to inculcate a belief in 'ultimate fulfillment' - that which finds its metaphorical reference in the "utopian microcosm of modern consumer society" (taken from Germain) - but the success of such consumer-commitment to elusive satisfaction means that all efficacy of critical theory and practice is undermined. This phenomenon can be referred to the "consumer fetishism" mentioned by Arjun Appadurai. ${ }^{4}$

It is worth noting that this phenomenon of consumerism has already attracted the attention of many researchers. In my opinion, it was best described by Zygmunt Bauman in his book Together, Apart (2003), in which he deliberately separates the notion of "consumptionism" from "consumerism". In Bauman's opinion, "consumerism" consists not so much in the accumulation of objects or material goods (which is characteristic of "consumptionism", and which limits human freedom as a result), but in their continuous exchange, rapid circulation or movement, with the consequence of deriving only occasional pleasure from them. What is worrying, because untenable - and this resonates with Germain's observations, discussed in the paper under review - is that consumerism appears here as a moral doctrine, a way to be happy, fulfilled (a way to satisfy both physical and spiritual needs and desires). 'Good' is identified here with 'material

4 In reference to Marx's famous view of fetishism, Arjun Appadurai derived the theory of "consumer fetishism" in the modern world, created as a result of the flood of goods and of media images (especially accompanying advertisements), thereby transforming the consumer. At the same time, global advertising is the key technology for a multitude of creative and well-chosen images pertaining to the consumer factor. These images distort the commodity reality; however, it happens in such a subtle way that the consumer usually does not realise it. Arjun Appadurai, Modernity at Large: Cultural Dimensions of Globalization, University of Minnesota Press 1996, pp.41-42. 
good(s)', and as belonging to the world of consumer symbols. ${ }^{5}$ Bauman's perspective is especially important to me as a researcher of communication and other relational processes because it draws attention to interpersonal relations and the educational aspect (learning in and through the culture in which we live). This perspective allows one to perceive countless traps of consumerism, where objects and people boil down to a common denominator, where things and social ties are to serve only for a certain period of time, as long as they can still be useful, exciting - before the next commodity comes along. In this logic, ageing, worn-out items and relationships should definitely be replaced by new, current models in the name of homo consumens' success (e.g. yesterday's computer for today's computer, yesterday's partner for today's partner $)^{6}$. This approach draws attention to the functional, instrumental treatment of human and interpersonal relationships, where the perspective of relating with anything/anyone for a longer period of time (and even for a whole life) is perceived as repugnant. Bauman's concept fits perfectly in the perspective of Germain, cited by the author, who is similarly concerned with the relation between humans and technology in a consumerist world.

In the paper under discussion, the author directs attention to the extremely sophisticated manipulation of consumers on the part of representatives and agencies of the modern, neoliberal world (armed or equipped with modern, dynamically developing technologies, by means of which new meanings and content are transferred and reproduced), unscrupulously used in the 'capitalist consumerism paradise' where the truly satisfied or fulfilled consumer becomes highly undesirable, inconvenient and a 'curse' to capitalism (after all, only the semblance of fulfillment is aimed for). Paradoxically, therefore, on the one hand the essence of such a world is the use of technology to manipulate people/ consumers in such a way that they feel 'unsaturated', unfulfilled (which in turn draws attention to the twisted logic used to manipulate people so that they [mis-] recognise the artificial needs imposed on them as their own needs). On the other hand, however, as Germain (cited in the paper concerned) argues, technology creates the impression that all needs can finally be satisfied on the part of consumers, so that desire itself - which presupposes human beings as striving, lacking beings in a world marked by openness - is eradicated in a technologysaturated world.

5 Zygmunt Bauman, Razem, osobno (Together, Apart), translated by: Tomasz Kunz, Wydawnictwo Literackie, Kraków 2003, pp.107-155; compare Zygmunt Bauman, Życie na przemiał, Wydawnictwo Literackie, Kraków 2004, pp.26-28.

6 Ibidem p.3 
In this context, we see that all the phenomena of the modern world (where consumption and technology are the defining ones) are interdependent, and at the same time constitute a sign of the instrumentalisation of culture and the objectivisation of human beings. In this world, the Enlightenment belief about the power of human reason loses its raison d'être and is supplanted by the free market and consumption (neoliberal culture). In the face of so many threats and pitfalls of the modern world as far as human emancipation goes, it is not surprising that the author so fervently warns us against the extremely limiting or constraining influence of neoliberal (consumer) capitalism and its culture, in which he sees a growing tendency to exercise extreme control over people and social life, thanks to the increasing use of information technologies. As a particularly disturbing phenomenon he recognises that their influence is constantly expanding, and accordingly increasing in the new spheres of human life, at the same time affecting human thinking, language and emotions, incorporating and creating new hierarchies of values in the world. This is because (as Germain demonstrates, and quoted by Olivier) "Our ability to articulate thoughts and feelings - and to some extent even to have them - is shaped both by the nature of the social order we inhabit, and by the character of our relations with this order." Therefore, what is particularly worrying for the author is the appropriation of human thinking, subjected to the clever 'propaganda' of the neoliberal world and its policy of seduction, which promotes a thoughtless pursuit of newly-generated needs, simultaneously pushing people into multiple forms of addiction or submission.

Representative mechanisms of enslavement are the four categories of subjectivity mentioned by Michael Hardt and Antonio Negri, cited in the text by the author, namely: indebtedness (an effective way of keeping people submissive, and under control), mediatization (manifesting the addiction to contemporary media and information), security (constituting a smokescreen and creating ostensible protection relating to the human sense of insecurity, but in fact subordinated to specific interests) and, the last category, representation (referring to the apolitical attitude of people who are actually [mis-]represented by those who care only about their particular interests). The author, citing a number of arguments pointing to the harmfulness of neoliberal (consumer) capitalism prevailing from the late $20^{\text {th }}$ century, also refers to other works by Hardt and Negri, namely Empire (2001) and Multitude (2005), which he uses extensively when arguing his position (and which relate to the newly created supranational, hegemonic world order established on four levels identified by the authors: political, economic, cultural and technological), of which he writes more 
broadly in a previous paper, namely: "Communication' in the era of 'Empire' and 'multitude'"(2007)7.

The essence of the discussed (extraordinarily extensive) work of Olivier, who treats the essence of critical theory in a responsible and serious way (linking the possibility of actual emancipation interpretively with critical thinking), is to look for a path towards the recovery of the critical ability to engage in real, unmitigated emancipatory actions. Following the ideas of Hardt and Negri, the author takes the position that it is not enough to think critically, but it is necessary to learn how to engage in critical action (derived from Kant's thinking about enlightenment and which also perfectly corresponds with the thinking of Hannah Arendt (whose way of thinking the author reconstructs). The latter distinguishes between "vita activa"/active life - where action and speech are an indispensable condition for being truly human - as no other human activity requires speech as much as action - and "vita contemplativa"/life of contemplation, which also exposes a sensitive or weak point of the mode of being based on contemplation, in isolation from the real world, adopted by the intellectual elites.

In this perspective, the author presents the attitude of philosophers or thinkers and other representatives of social elites, who are exposed to uncompromising criticism for their attitude towards 'critical thinking', affirming stagnation, passivity, or indifference to the world, or lack of courage, even cowardice. At this point, it is impossible not to refer to the book by Julien Benda: The Treason of the Intellectuals (La Trahison des Clercs) ${ }^{8}$, which very strongly corresponds with the argument of the author's text. Benda blames the intellectual elites (who cut themselves off from the current social and political life, but willingly enjoy 'creation for creation's sake') for betraying the basic principles or values: Truth, Justice, Good, and with these also themselves and humanity. As one can see, the message of Olivier's paper resonates unmistakably with Benda's. Both seem to be equally uncompromising, categorical and at the same time full of concern for the future of the world.

Recalling the work of Naomi Klein, Olivier also draws attention to the numerous harmful activities of the social elites, whose representatives act unscrupulously, ruin the economy, the natural environment, and deepen the phenomenon of poverty and destitution in the modern world (based on an unjust and harmful social order). At the same time, the author emphasises numerous limitations and oppositions that stand in the way of recovering the capacity for

7 Communicatio (South African Journal for Communication Theory and Research), Vol. 33 (1), 2007, pp. 42-61.

8 Julien Benda: Zdrada klerków (La Trahison des Clercs), translated by:Marek J. Mosakowski, Wydawnictwo Krytyki Politycznej, Warszawa 2014. 
truly emancipatory actions by critical theory, which concerns intellectual elites who, instead of fulfilling their role of counselling in the interest of basic values, have in fact remained passive, as well as economic elites creating a contemporary neoliberal (consumer) culture, which has in turn degraded existing values.

The author notes that although critical theory, by analogy with psychoanalysis, can prepare a human being for action in socio-political reality (pointing out the differences between theory and action or between reason and practice), there is no guarantee that theory will always be put into action, and reason or theory into practice. However, he does not stop at purely theoretical analysis, but also refers to specific examples illustrating his argumentative line. The examples cited are taken from real/everyday life, constituting in my opinion the clue to comprehending the presented considerations or reflections and perfectly complementing them. They show that every activity/action in the interest of freedom or independence, improves and changes the world for the better and guides people towards their liberation or emancipation, although sometimes such actions result in more or less severe consequences, which do not, however, negate the value of the actions. As the author says, these consequences are not a sufficient reason not to act. In my opinion, such actions are a perfect, inspiring example for others, and they encourage similar activities, building a sense of community/solidarity with all those who act in this way. They are also the basis for restoring the already dilapidated moral values - something that we long for. However, recuperating these values requires action and the courage to act. 